\title{
RANCANG BANGUN SISTEM MONITORING KEAMANAN RUMAH BERBASIS WEB MENGGUNAKAN RASPBERRY PI B+ SEBAGAI SERVER DAN MEDIA KONTROL
}

\author{
Muhammad Khoiru Syabibi, Arkhan Subari \\ Program Studi Diploma III Teknik Elektro \\ Sekolah Vokasi Universitas Diponegoro
}

\begin{abstract}
Muhammad Khoiru Syabibi, Arkhan Subari in this paper explain that Along with the progress of era, the development of advanced technology also impacts on the development of security systems. Sophisticated security systems that digitally integrated has been growing, one of them is a web-based security system.

This web-based home security monitoring system uses a raspberry pi $b+$ that serves as a server and media controller, then for the web programming, it uses HTML, CSS and Javascript. This web-based home security monitoring system home uses a webcam (web camera) that functions like CCTV which can be monitored via a web browser, magnetic switch as security detector, keypad as access control to turn off security monitoring system for 10 seconds, and the buzzer and LED as security indicators.

When someone enter the house, he/she must press the keypad. If keypad input is correct according to the passcode then the LED will turn off, indicate that home security monitoring system off for 10 seconds. If he/she enter the house without pressing the keypad according to the passcode then when the door opens, a switch magnetic will active, then buzzer will sound and the indicator on the web will change, indicate that he/she is a person who will do the crime.

Keyword : raspberry pi b+, webcam, magnetic switch, keypad, buzzer and LED
\end{abstract}

\section{PENDAHULUAN}

Di zaman modern ini, seiring dengan semakin maraknya kasus kriminalitas, kebutuhan manusia akan rasa aman terus meningkat. Seiring perkembangan teknologi, semakin banyak peralatan-peralatan maupun sistem keamanan canggih berbasis teknologi yang mutakhir. Semakin tingginya angka kriminalitas terutama pencurian dan perampokan mendorong diperlukannya sistem keamanan yang lebih efektif dan efisien, apalagi di zaman serba IT ini, sistem keamanan yang terkoneksi secara digital, yang dapat dipantau dari mana saja mutlak semakin diperlukan.

Saat ini teknologi sistem keamanan memang sudah berkembang dengan sangat pesat, mulai dari yang paling sederhana hingga menggunakan teknologi yang canggih seperti teknologi kamera CCTV, baik CCTV dengan sistem offline maupun CCTV dengan sistem online yang menggunakan IP camera. Namun, teknologi sistem keamanan yang ada di Indonesia kebanyakan adalah produksi dari pabrik dengan harga yang mahal. Kondisi ini menyebabkan tidak banyak rumah yang menggunakan teknologi sistem keamanan tersebut karena harganya yang mahal. Diperlukan suatu sistem keamanan yang lebih murah, juga lebih mudah, efektif dan efisien, sehingga bisa dijangkau oleh semua kalangan.

Kondisi di atas mendorong penulis membuat sebuah sistem monitoring keamanan, di mana sistem monitoring keamanan ini menggunakan Webcam(Web Camera) sebagai alat untuk memantau keamanan secara realtime melalui web browser, switch magnetik sebagai sensor pendeteksi keamanan, buzzer sebagai alarm indikator, LED sebagai on/off indikator serta keypad sebagai akses kontrol untuk menghidupkan dan mematikan alarm. Sistem monitoring keamanan rumah berbasis web ini menggunakan Raspberry Pi $B+$ yang berfungsi sebagai server dan media kontrol rangkaian.

\section{Batasan Masalah}

Pada penelitian yang dilakukan ini terdapat beberapa batasan yaitu:

- Membahas mini PC raspberry pi B+ sebagai server dan media kontrol pada rangkaian sistem monitoring keamanan rumah.

- Membahas webcam sebagai alat untuk memantau keamanan secara realtime melalui web browser.

- Membahas switch magnetik sebagai sensor pendeteksi keamanan.

- Membahas buzzer dan LED sebagai indikator sistem monitoring keamanan rumah.

- Membahas keypad sebagai akses kontrol untuk mematikan sistem alarm keamanan.

- Membahas sistem web dan bahasa-bahasa pemrograman yang digunakan dalam sistem monitoring keamanan rumah

\section{Tujuan Penelitian}

Adapun tujuan yang ingin dicapai penulis dalam tugas akhir ini adalah membuat suatu sistem monitoring keamanan rumah berbasis web, menggunakan webcam sebagai alat untuk memantau keamanan secara realtime, switch magnetik sebagai 
sensor pendeteksi keamanan, buzzer dan LED sebagai indikator sistem monitoring keamanan rumah serta keypad sebagai akses kontrol untuk menghidupkan dan mematikan sistem alarm keamanan

\section{DASAR TEORI}

Raspberry Pi

Raspberry Pi adalah komputer berukuran kecil yang dikembangkan di Inggris oleh Yayasan Raspberry $P i$ dengan tujuan untuk mempromosikan pengajaran dasar ilmu komputer di sekolah. Raspberry $\mathrm{Pi}$ diproduksi melalui lisensi manufaktur yang berkaitan dengan elemen 14/Premier Farnell dan RS komponen. Perusahaan ini menjual Raspberry Pi secara online.

Raspberry $P i$ memiliki sistem Broadcom BCM2835 chip (SoC), yang mencakup ARM1176JF$\mathrm{S} \mathrm{MHz} \mathrm{processor} \mathrm{(firmware} \mathrm{termasuk} \mathrm{sejumlah} \mathrm{mode}$ "Turbo" sehingga pengguna dapat mencoba overlocking hingga $1 \mathrm{GHz}$ tanpa mempengaruhi garansi), VideoCore IV GPU, dan awalnya dibuat dengan $256 \mathrm{Mb}$ RAM, kemudian di-upgrade hingga 512 MB. Termasuk harddisk built-in atau solid-state drive, akan tetapi $S D$ Card digunakan untuk booting dan penyimpanan jangka panjang.

Yayasan ini memberikan Debian dan Arch Linux ARM untuk di-download. Juga mendukung Python sebagai bahasa pemrograman utama dengan dukungan untuk BBC BASIC, (melalui gambar RISC PS atau clone "Brendy Basic" untuk Linux, C, dan Perl)

Raspberry pi merupakan sistem operasi berbasis Debian yang dapat bebas dioptmalkan untuk prangkat keras Raspberry pi. GPU hardware diakses melalui firmware yang diload ke GPU saat boad dari SD card. Frimware biasa dikenal dengan kumpulan biner. API driver kernel untuk perpustakaan tersebut bersifat tertutup. Aplikasi video yang menggunakan OpenMax, aplikasi 3D, menggunakan OpenGL, ES dan aplikasi 2D menggunakan OpenVG yang pada nantinya akan menggunakan EGL. OpenMax dan EGL menggunakan open source kernel driver.

Yayasan Raspberry pi merilis bukti konsep kartu SD image yang dapat dimuat ke SD Card untuk menghasilkan sebuah sistem oprasi yang pertama. Image didasarkan pada Debian 6.0 dengan LXDE desktop dan Midoro browser, ditambah berbagai alat pemrograman. Image tersebut berjalan pada QEMU yang memungkinkan Raspberry pi dapat ditiru pada berbagai platform lainnya.

Raspberry Pi Model B memiliki :

- Pin GPIO yang lebih banyak. Header pin GPIO telah berkembang menjadi 40 pin, sementara Pin GPIO pada raspberry pi model lama 26 pin.
- Port USB Lebih. Raspberry Pi B memiliki 4 port USB 2.0, dibandingkan dengan 2 pada Model lama, dan hotplug lebih baik dan perilaku arus lebih.

- Micro SD. Socket SD card pada Raspberry Pi B telah digantikan dengan socket micro SD.

- Konsumsi daya yang lebih rendah dibanding raspberry pi model lama.

- Kualitas Audio yang lebih baik. Rangkaian Audio pada raspberry pi b menggabungkan suara rendah dengan catu daya khusus.

- Faktor bentuk yang lebih rapi. Raspberry Pi B telah selaras antara konektor USB dengan papan, antara video komposit ke jack $3.5 \mathrm{~mm}$

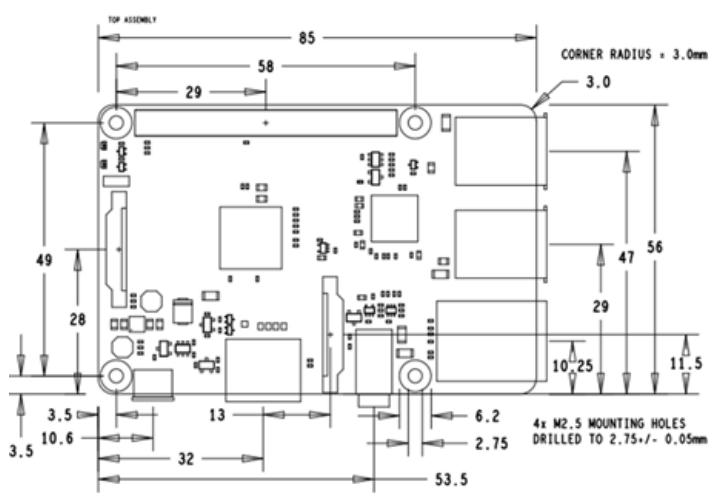

Gambar 1. Arsitektur Raspberry Pi

Raspberry $P i$ sebagai sebuah komputer, utamanya sebagai sebuah komputer mini tersusun atas beberapa bagian perangkat keras atau hardware.

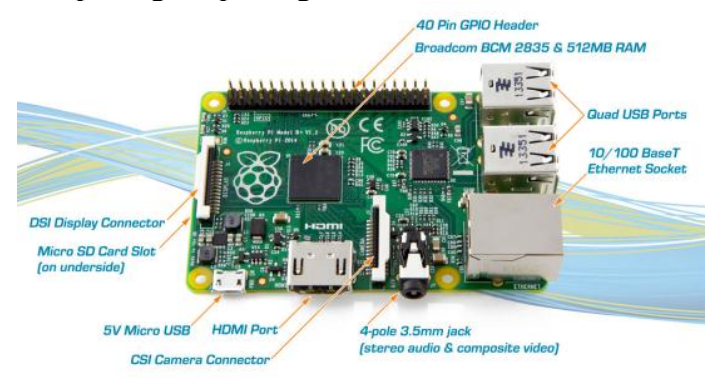

Gambar 2. Raspberry Pi

Hardware atau perangkat keras dari Raspberry

$P i$ terdiri dari 10 bagian utama yaitu:

- Broadcom BCM2835 \& 512MB RAM

- HDMI Port

- CSI Connector Camera

- Ethernet Socket

- Quad USB Port

- 4-Pole $3.5 \mathrm{~mm}$ Jack sebagai stereo audio dan video output.

- 40 pin GPIO Header

- DSI Display Connector

- Micro SD Card Slot

- Micro USB power 


\section{Webcam}

Webcam merupakan gabungan dari kata web dan camera. Webcam sendiri sebutan bagi kamera real-time (bermakna keadaan pada saat ini juga) yang gambarnya bisa diakses atau dilihat melalui internet, program instant messaging seperti Yahoo Messenger, AOL Instant Messenger(AIM), Windows Live Messenger, dan Skype, dan lainnya. Istilah "webcam" sendiri mengarah pada jenis kamera yang digunakan untuk kebutuhan layanan berbasis web. Webcam sendiri biasanya digunakan untuk keperluan konferensi jarak jauh atau juga sebagai kamera pemantau. Webcam merupakan hardware yang sangat penting pada sistem monitoring ini karena digunakan untuk memonitor kondisi keamanan ruangan.

Webcam adalah sebuah periferal berupa kamera sebagai pengambil citra/gambar dan mikrofon (optional) sebagai pengambil suara/audio yang dikendalikan oleh sebuah komputer atau oleh jaringan komputer. Gambar yang diambil oleh webcam ditampilkan ke layar monitor, karena dikendalikan oleh komputer maka ada interface atau port yang digunakan untuk menghubungkan webcam dengan komputer atau jaringan. Ada beberapa orang mengartikan webcam sebagai web pages + camera, karena dengan menggunakan webcam untuk mengambil gambar video secara aktual bisa langsung diupload bila komputer yang mengendalikan terkoneksi internet.

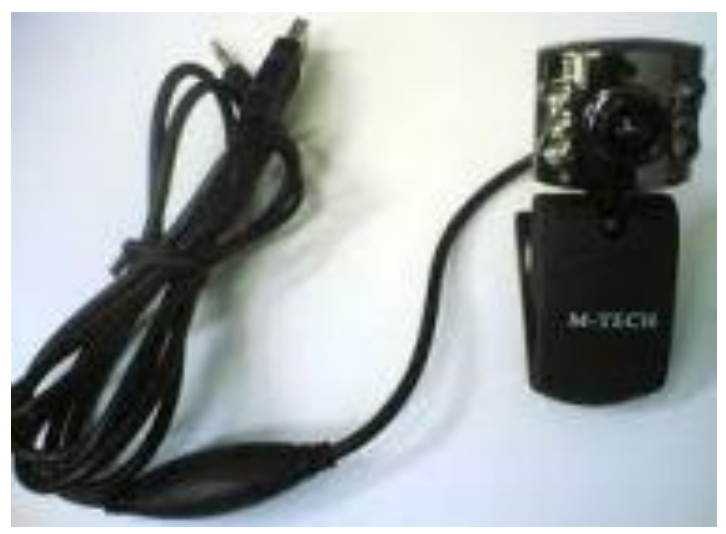

Gambar 3. Webcam

Sebuah webcam yang sederhana terdiri dari sebuah lensa standar, dipasang di sebuah papan sirkuit untuk menangkap sinyal gambar; casing (cover), termasuk casing depan dan casing samping untuk menutupi lensa standar dan memiliki sebuah lubang lensa di casing depan yang berguna untuk memasukkan gambar; kabel support, yang dibuat dari bahan yang fleksibel, salah satu ujungnya dihubungkan dengan papan sirkuit dan ujung satu lagi memiliki connector, kabel ini dikontrol untuk menyesuaikan ketinggian, arah dan sudut pandang web camera. Sebuah web camera biasanya dilengkapi dengan software, software ini mengambil gambargambar dari kamera digital secara terus menerus ataupun dalam interval waktu tertentu dan menyiarkannya melalui koneksi internet. Ada beberapa metode penyiaran, metode yang paling umum adalah hardware mengubah gambar ke dalam bentuk file JPG dan menguploadnya ke web server menggunakan File Transfer Protocol (FTP).

\section{Switch Magnetik}

Switch magnetik merupakan saklar yang dapat merespon medan magnet yang berada disekitarnya. Magnetik switch ini seperti halnya sensor limit switch yang diberikan tambahan plat logam yang dapat merespon adanya magnet. Switch magnetik mempunyai 4 komponen yaitu magnet, switch dengan terminal sekrup, tutup terminal sekrup dan kabel penghubung.

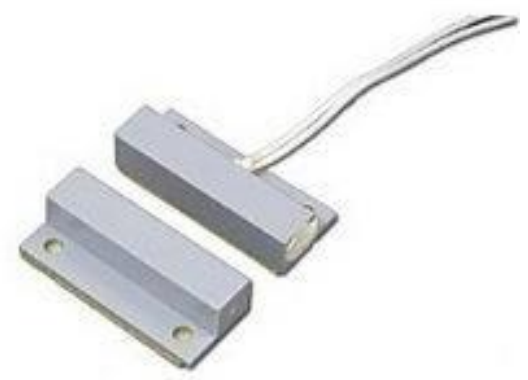

Gambar 4. Switch Magnetik

Switch magnetik ini pada dasarnya cara kerjanya sama dengan reed switch. Saat satu bagian switch magnetik terpasang pada pintu dan satu bagian lain pada bingkai pintu. Satu dari dua bagian tersebut mengandung magnet, sedang pada bagian yang lain terdapat reed switch yang akan tertutup ketika dekat dengan magnet. Ketika kedua bagian tersebut terpisah, maka medan magnet akan kehilangan kekuatannya, dan rangkaian akan terputus. Switch magnetik ini bersifat normally open. Jadi, ketika pintu tertutup, maka arus mengalir melalui switch, ketika pintu terbuka, maka arus akan terputus.

\section{Buzzer}

Buzzer adalah sebuah komponen elektronika yang berfungsi untuk mengubah getaran listrik menjadi getaran suara. Pada dasarnya prinsip kerja buzzer hampir sama dengan loud speaker, jadi buzzer juga terdiri dari kumparan yang terpasang pada diafragma dan kemudian kumparan tersebut dialiri arus sehingga menjadi elektromagnet, kumparan tadi akan tertarik ke dalam atau keluar, tergantung dari arah arus dan polaritas magnetnya, karena kumparan dipasang pada diafragma maka setiap gerakan kumparan akan menggerakkan diafragma secara 
bolak-balik sehingga membuat udara bergetar yang akan menghasilkan suara. Buzzer biasa digunakan sebagai indikator bahwa proses telah selesai atau terjadi suatu kesalahan pada sebuah alat (alarm).

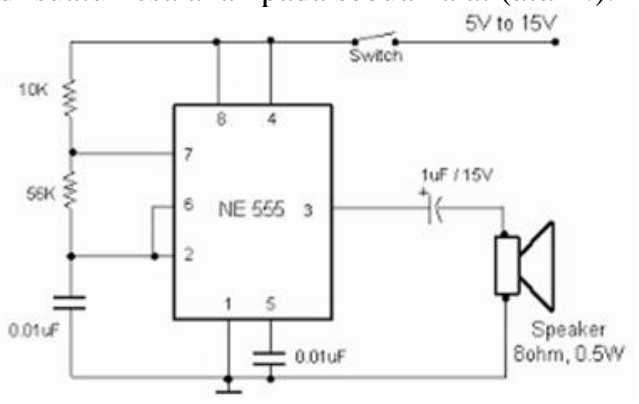

Gambar 5. Rangkaian Buzzer

Dari Gambar 5. rangkaian, dapat dijelaskan bahwa saat sakelar aktif, maka arus akan mengalir ke IC 555 dan potensiometer. IC berfungsi untuk membangkitkan pulsa. Kemudian arus diteruskan ke transistor kaki emitor. Keluaran dari IC (kaki 3) tersambung ke Basic transistor.

Keluaran dari IC berfungsi untuk memberi picuan terhadap transistor. Akibatnya arus mengalir dari emitor ke kolektor ( dalam hal ini transistor berfungsi sebagai sakelar). Lalu arus dari kolektor digunakan untuk mengaktifkan buzzer dan LED. Dan untuk mengatur frekuensinya digunakan potensiometer

\section{Light Emirtting Diode (LED)}

Light Emitting Diode atau sering disingkat dengan LED adalah komponen elektronika yang dapat memancarkan cahaya monokromatik ketika diberikan tegangan maju. LED merupakan keluarga Dioda yang terbuat dari bahan semikonduktor. Warna-warna Cahaya yang dipancarkan oleh LED tergantung pada jenis bahan semikonduktor yang dipergunakannya. LED juga dapat memancarkan sinar inframerah yang tidak tampak oleh mata seperti yang sering kita jumpai pada Remote Control TV ataupun Remote Control perangkat elektronik lainnya.

Bentuk LED mirip dengan sebuah bohlam (bola lampu) yang kecil dan dapat dipasangkan dengan mudah ke dalam berbagai perangkat elektronika. Berbeda dengan Lampu Pijar, LED tidak memerlukan pembakaran filamen sehingga tidak menimbulkan panas dalam menghasilkan cahaya. Oleh karena itu, saat ini LED (Light Emitting Diode) yang bentuknya kecil telah banyak digunakan sebagai lampu penerang dalam LCD TV yang mengganti lampu tube.

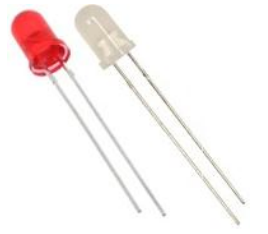

Gambar 6. Light Emitting Diode (LED)

LED merupakan keluarga dari dioda yang terbuat dari Semikonduktor. Cara kerjanya hampir sama dengan dioda yang memiliki dua kutub yaitu kutub positif $(\mathrm{P})$ dan kutub negatif $(\mathrm{N})$. LED hanya akan memancarkan cahaya apabila dialiri tegangan maju (bias forward) dari anoda menuju ke katoda.

LED terdiri dari sebuah chip semikonduktor yang didoping sehingga menciptakan junction $\mathrm{P}$ dan N. Yang dimaksud dengan proses doping dalam semikonduktor adalah proses untuk menambahkan ketidakmurnian (impurity) pada semikonduktor yang murni sehingga menghasilkan karakteristik kelistrikan yang diinginkan. Ketika LED dialiri tegangan maju atau bias forward yaitu dari Anoda (P) menuju ke Katoda (K), Kelebihan Elektron pada N-Type material akan berpindah ke wilayah yang kelebihan Hole (lubang) yaitu wilayah yang bermuatan positif (P-Type material). Saat Elektron berjumpa dengan Hole akan melepaskan photon dan memancarkan cahaya monokromatik (satu warna)

\section{Keypad}

Keypad berarti sebuah keyboard miniatur atau set tombol untuk operasi portabel perangkat elektronik, telepon, atau peralatan lainnya. Keypad merupakan sebuah rangkaian tombol yang tersusun atau dapat disebut "pad" yang biasanya terdiri dari huruf alfabet $(\mathrm{A}-\mathrm{Z})$ untuk mengetikkan kalimat, juga terdapat angka serta simbol-simbol khusus lainnya.

Keypad adalah saklar-saklar push button yang disusun secara matriks yang berfungsi untuk menginput data seperti, input pintu otomatis, input absensi, input datalogger dan sebagainya. Saklarsaklar push button yang menyusun keypad yang digunakan umumnya mempunyai 3 kaki dan 2 kondisi.

Salah satu jenis perangkat antar muka yang umum dijumpai pada sistem embedded adalah keypad membrane $3 \times 4$ atau 4x4. Keypad biasanya digunakan pada beberapa peralatan yang berbasis mikrokontroller. Keypad berfungsi sebagai interface antara perangkat (mesin) elektronik dengan manusia atau dikenal dengan istilah HMI (Human Machine Interface). Keypad membrane 4x3 adalah keypad dengan jumlah kolom 3 dan jumlah baris 4 yang dapat digunakan, sedangkan keypad membrane 4x4 adalah keypad dengan jumlah kolom 4 dan jumlah baris 4 yang dapat digunakan. 


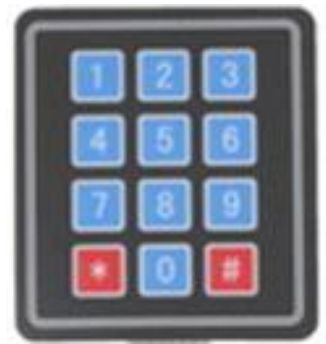

Gambar 7. Keypad 4x3

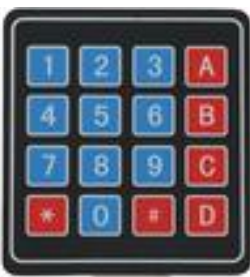

Gambar 8. Keypad 4x4

\section{Cara Kerja Sistem Monitoring Blok Diagram Sistem}

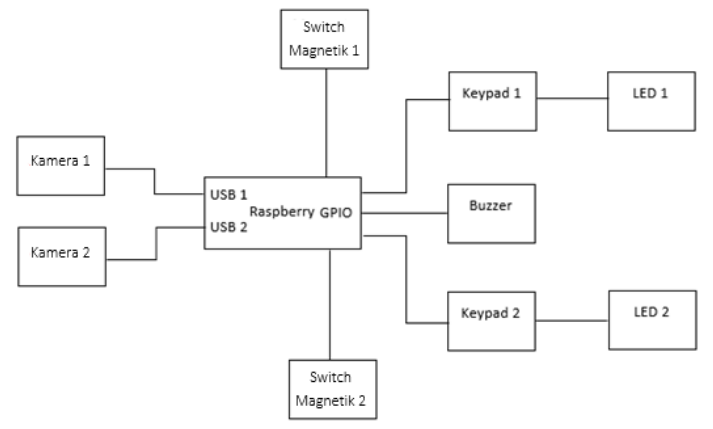

Gambar 9. Blok Diagram Sistem Monitoring Keamanan

Sistem monitoring keamanan ini terdiri atas beberapa bagian penting yaitu raspberry pi $b+$ sebagai server dan media kontrol sistem keamanan, 2 buah webcam yang difungsikan sebagai CCTV, 2 buah switch magnetik sebagai sensor pendeteksi pada sistem monitoring keamanan, 2 buah keypad sebagai akses kontrol untuk mematikan sistem monitoring keamanan, buzzer dan LED sebagai indikator sistem monitoring keamanan, phyton sebagai bahasa program yang dituliskan pada raspberry pi sesuai dengan kebutuhan alat. Sedangkan bahasa pemrograman pada web menggunakan bahasa pemrograman html (hypertext markup language), php(Hypertext Preprocessor) dan javascript.

Proses bekerjanya sistem monitoring keamanan ini diawali. Untuk mematikan sistem alarm pada sistem monitoring keamanan, maka pemilik/orang yang akan masuk harus menekan kombinasi angka pada keypad sesuai kombinasi yang telah diatur pada program. Jika kombinasi angka cocok, maka LED yang tadinya dalam kondisi on akan off, sistem alarm pada sistem monitoring keamanan dalam keadaan tidak aktif, setelah itu selang 10 detik, secara otomatis sistem monitoring akan aktif kembali.

Dalam rangkaian, sebagai sensor pendeteksian pada sistem monitoring keamanan, digunakan switch magnetik. Switch magnetik ditempatkan pada pintu ruangan yang akan dimonitoring keamanannya. Ruangan yang akan dimonitoring adalah ruangan yang potensi terjadinya pencurian cukup tinggi, contohnya adalah pintu depan rumah ataupun pintu gudang penyimpanan.

Saat kondisi normal, tampilan pada web menunjukkan bahwa pintu dalam keadaan tertutup. Ketika pintu terdobrak, maka switch magnetik akan aktif. Ketika switch magnetik aktif, maka switch magnetik akan mengirimkan input ke raspberry pi. Raspberry $P i$ yang mendapat input dari switch magnetik berupa dobrakan pada pintu akan mengolah input itu sesuai dengan program yang telah ditanamkan pada raspberry pi. Saat kondisi sistem alarm pada system monitoring keamanan aktif(LED on), apabila ada input dari switch magnetik mendeteksi gerakan manusia, maka raspberry pi akan mengaktifkan buzzer, kemudian pada tampilan web akan ada perubahan berupa indikator gambar bergerak yang menunjukkan bahwa pintu telah terdobrak. Selanjutnya buzzer berbunyi, sebagai indikator adanya orang yang mendobrak pintu ruangan tersebut. Sedangkan saat kondisi sistem alarm pada sistem monitoring keamanan tidak aktif(LED off), apabila ada input dari switch magnetik mendeteksi gerakan manusia, maka buzzer tidak berbunyi.

\section{Flowchart Sistem Monitoring Keseluruhan}



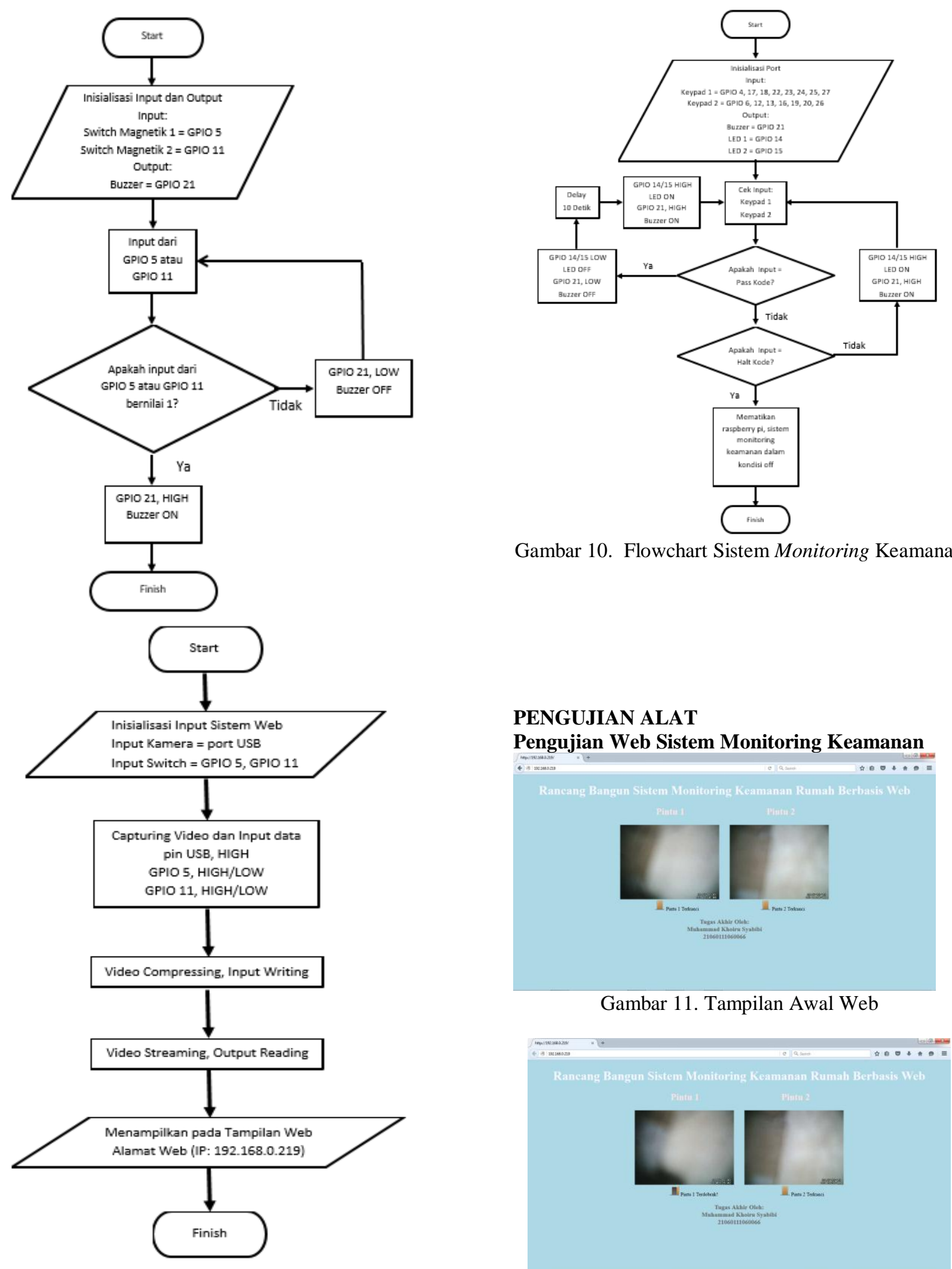

Gambar 10. Flowchart Sistem Monitoring Keamanan

\section{PENGUJIAN ALAT}

Pengujian Web Sistem Monitoring Keamanan

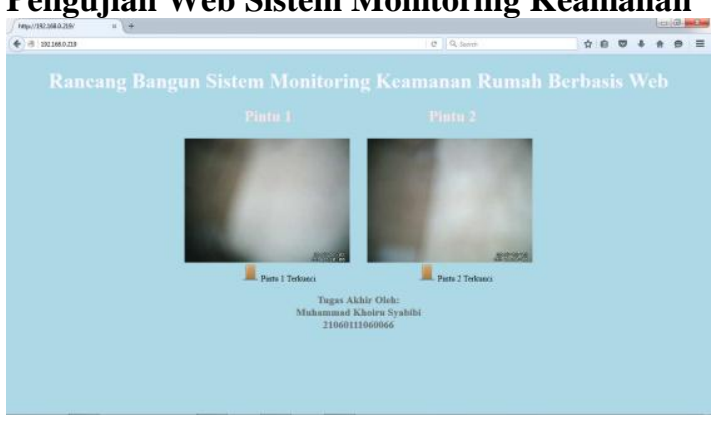

Gambar 11. Tampilan Awal Web

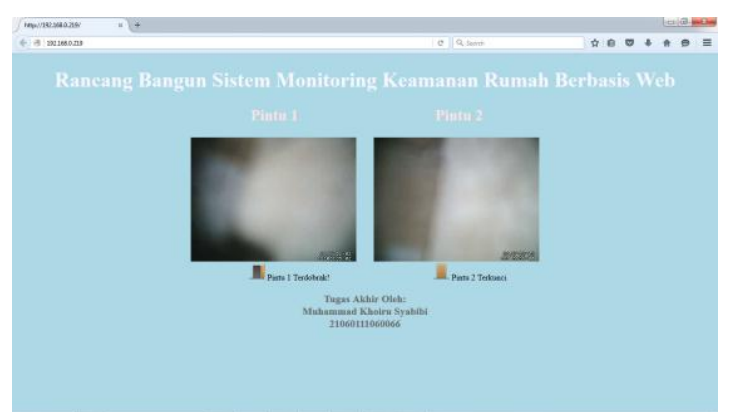

Gambar 12 Hasil Tampilan Web Saat Pintu 1 Dibuka 


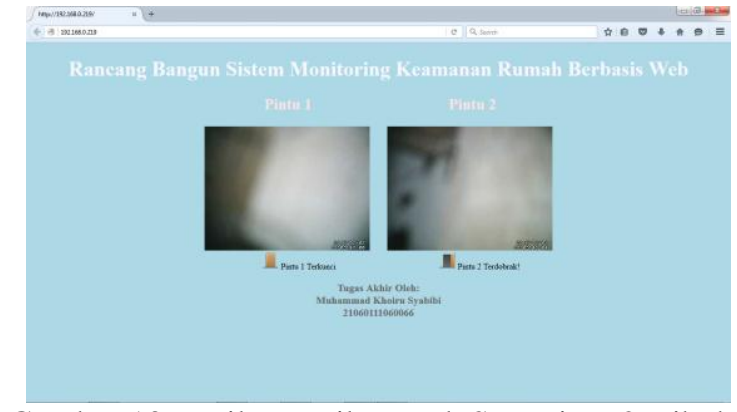

Gambar 13 Hasil Tampilan Web Saat Pintu 2 Dibuka

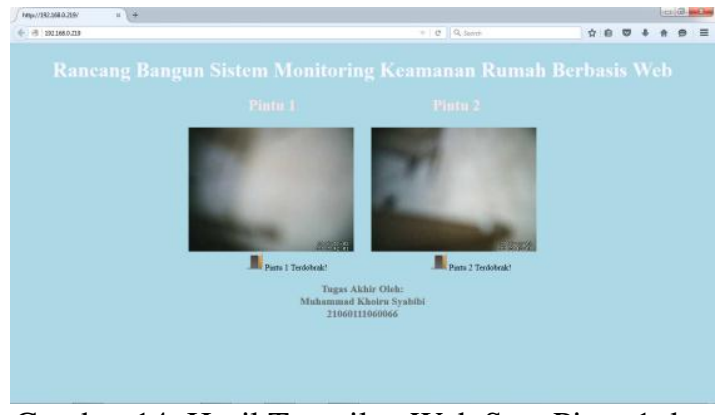

Gambar 14. Hasil Tampilan Web Saat Pintu 1 dan Pintu 2 Dibuka

\section{Pengujian Rangkaian Alarm}

Pada rangkaian alarm monitoring keamanan dilakukan beberapa kali pengujian. Pengujian itu antara lain, pengujian pada pintu 1 , pengujian pada pintu 2, dan pengujian pada kedua pintu.

Tabel 1. Pengujian Rangkaian Alarm

\begin{tabular}{ccccc}
\hline No & \multicolumn{2}{c}{ Kondisi Pintu } & Buzzer & Kondisi \\
& Pintu1 & Pintu2 & & Alarm \\
\hline 1 & Tertutup & Tertutup & Off & aktif \\
2 & Terbuka & Tertutup & On & aktif \\
3 & Tertutup & Terbuka & On & aktif \\
4 & Terbuka & Terbuka & On & aktif \\
5 & Terbuka & Terbuka & Off & non aktif \\
\hline
\end{tabular}

\section{Pengujian Rangkaian Akses Kontrol}

Pada rangkaian akses kontrol monitoring keamanan dilakukan beberapa kali pengujian. Pengujian itu antara lain, pengujian pada keypad 1 dan pengujian pada keypad 2 .

Tabel 2. Pengujian Rangkaian Akses Kontrol

\begin{tabular}{|c|c|c|c|c|c|}
\hline \multirow[t]{2}{*}{ No } & \multicolumn{2}{|c|}{ Input Keypad } & \multicolumn{2}{|c|}{ LED } & \multirow[t]{2}{*}{ Delay(s) } \\
\hline & Keypad1 & Keypad2 & LED1 & LED2 & \\
\hline 1 & $\begin{array}{c}\text { Sesuai } \\
\text { Passcode }\end{array}$ & $\begin{array}{c}\text { Selain } \\
\text { Passcode }\end{array}$ & Off & On & 10 \\
\hline 2 & $\begin{array}{c}\text { Selain } \\
\text { Passcode }\end{array}$ & $\begin{array}{c}\text { Sesuai } \\
\text { Passcode }\end{array}$ & On & Off & 10 \\
\hline 3 & $\begin{array}{c}\text { Sesuai } \\
\text { Passcode }\end{array}$ & $\begin{array}{c}\text { Sesuai } \\
\text { Passcode }\end{array}$ & Off & Off & 10 \\
\hline 4 & $\begin{array}{c}\text { Selain } \\
\text { Passcode }\end{array}$ & $\begin{array}{c}\text { Selain } \\
\text { Passcode }\end{array}$ & On & On & 10 \\
\hline 5 & $\begin{array}{c}\text { Sesuai } \\
\text { Haltcode }\end{array}$ & $\begin{array}{c}\text { Sesuai } \\
\text { Haltcode }\end{array}$ & On & On & 10 \\
\hline
\end{tabular}

\section{PENUTUP}

Dari hasil penelitian yang dilakukan dapat disimpulkan beberapa hal yaitu:

- Sistem monitoring keamanan berbasis web menggunakan input berupa webcam, switch magnetik dan keypad, serta output berupa LED dan buzzer.

- Pada pembuatan aplikasi web sistem monitoring keamanan, digunakan apache sebagai web server, lalu untuk bahasa pemrograman web, digunakan bahasa pemrograman html, css, dan javascript, sedangkan untuk mengontrol input dan output pada GPIO raspberry pi, digunakan bahasa pemrograman python.

- Rangkaian alarm pada sistem monitoring keamanan berbasis web dalam kondisi aktif akan bekerja ketika ada perubahan dari kondisi pintu. Ketika pintu terbuka maka buzzer akan on, kemudian ketika pintu tertutup maka buzzer kembali off. Apabila rangkaian alarm dalam kondisi nonaktif, ketika pintu terbuka maka buzzer tetap dalam kondisi off.

- Pada rangkaian akses kontrol sistem monitoring keamanan, ketika input dari keypad sesuai passcode, maka LED akan off, menandakan rangkaian alarm dalam kondisi nonaktif selama 10 detik, Apabila input dari keypad selain passcode, maka LED tetap dalam kondisi on, menandakan rangkaian alarm dalam kondisi aktif. Namun, apabila input dari keypad sesuai haltcode, maka akan mematikan raspberry pi, sistem monitoring keamanan dalam keadaan off.

Sebagai bahan penelitian selanjutnya maka penulis menyarankan beberapa hal sebagai berikut :

- Untuk pengembangan sistem monitoring keamananan berbasis web selanjutnya bisa ditambahkan sistem database untuk mempermudah pengecekan perubahan kondisi sistem monitoring keamanan secara berkala.

- Untuk koneksi jaringan web bisa dikembangkan lagi dari localhost menjadi internet network yang dimana lebih efektif dalam pemakaiannya yang tidak terlalu mempertimbangkan jarak dan efisien dalam penggunaannya terutama penggunaan kabel lan, lalu untuk alamat ip raspberry pi akan lebih simple bila menggunakan ip public.

- Untuk pengembangan sistem monitoring keamanan berbasis web selanjutnya bisa ditambahkan sistem notifikasi berbasis sms, email maupun sistem notifikasi berbasis aplikasi android.

- Perlunya sumber catu daya cadangan agar ketika suplai catu daya utama (PLN) mati, sistem monitoring keamanan masih bisa tetap berjalan. Sehingga keamanan rumah terawasi 24 jam. 


\section{DAFTAR PUSTAKA}

1. Andre. 2014. Sejarah PHP dan Perkembangan Versi PHP. http://www.duniailkom.com/sejarahphp-dan-perkembangan-versi-php.

2. Apache Software Foundation. About the Apache HTTP Server Project. http://httpd.apache.org/ABOUT_APACHE.html.

3. Arfa. 2014. Akses Kontrol Kendaraan Bermotor Roda Empat Menggunakan Password dan Sensor. Skripsi. Jakarta: STMIK Raharja.

4. Aziz, Abdul. 2012. Pengertian, Fungsi, Serta Cara Kerja Web Server. http://www.dedeerik.com/pengertian-fungsi-sertacara-kerja-web-server.

5. Baharudin, M. 2011. Pengertian Website. http://www.naevaweb.com/pengertianwebsite/arsip.html.

6. Cox, Tim. 2014. Raspberry Pi Cookbook. Birmingham: Packt Publishing.

7. Embedded Linux Wiki. Raspberry Pi, Low-level Peripherals. level_peripherals.

8. Embededdlinux. Raspberry Mode B-Block diagram. Diunduh http://embeddelinux01.com.

9. Faizal. 2011. Prinsip Kerja Piezoelectric. http://www.insinyoer.com/prinsip-kerjapiezoelectric.

10. Friedl, Stave. 2015. Secure Linux/Unix Access With Putty and Open SSH. http://unixwiz.net/techtips/puttyopenssh.html/2015.

11. Gudang Linux. 2011. Python. http://gudanglinux.com/glossary/python.

12. Gurevich, Vladimir. 2011. Electric Relays: Principles and Applications. London: CRC Press.

13. Harian Android. 2014. Pengertian dan Fungsi SD Card.

http://www.harianandroid.com/2014/04/pengertia n-dan-fungsi-sd-card.html.

14. Heranudin. 2011. Rancang Bangun Sistem Keamanan Ruangan Menggunakan Radio Frequency. Skripsi. Depok: FT UI.

15. Iswan, Agusta. 2012. Sistem Proteksi Brankas Berpassword Menggunakan Magnetic Doorlock sebagai Penggerak Doorstrike Berbasis Mikrokontroller. Tugas Akhir D3 Teknik Elektro. Semarang: FT UNNES.

16. Kho, Dickson. 2012. Dioda dan Fungsi Dioda. http://teknikelektronika.com/-dioda-fungsi-dioda.

17. Kho, Dickson. 2012. Pengertian LED (Light Emitting Diode) dan Cara Kerjanya. http://teknikelektronika.com/pengertian-led-lightemitting-diode-cara-kerja.

18. Kho, Dickson. Pengertian Resistor dan Jenis Resistor. http://teknikelektronika.com/pengertianresistor-jenis-jenis-resistor.
19. Komponen Elektronika. 2011. Rangkaian Buzzer. http://komponenelektronika.com/rangkaianbuzzer.html.

20. MS-1 Magnetic Door Switch datasheet. http://www.braude.ac.il/files/departments/electric al_electronic_engineering/labs/data_pages/p3.pdf

21. Nasih, Muhammad Usman. 2013. Alat Pengaman Kendaraan Bermotor Menggunakan Password dan SMS. Tugas Akhir. Yogyakarta: STMIK El Rahma.

22. Özcan, Yakut. 2014. Piezoelektrik.

23. Paul Malvino, Albert. 2010. Prinsip-Prinsip Elektronika. Jakarta: Erlangga.

24. Pemrograman Komputer. 2012. Petunjuk Praktikum Pemrograman Komputer. Semarang: D3 Teknik Elektro UNDIP.

25. Prayitno, Indra. 2010. Kupas Tuntas Malwar. Jakarta: Elex Media Komputindo.

26. Raspberry Pi Fondation. GPIO Raspberry Pi Model $A$ dan $B$. https://www.raspberrypi.org/documentation/usage /gpio/2009

27. Raspberry Pi Fondation. Setting Up And Apache Web Server On A Raspberry Pi. https://www.raspberrypi.org/documentation/remot e-access/web-server/apache.md.

28. Raspberrry Pi Fondation. SSH Using Windows. http://raspberrypi.org/documentation/remoteaccess/ssh/windows.md/2014

29. Richardson, Matt dan Shawn Wallace. 2015. Make: Getting Started with Raspberry Pi. Sebastopol: Maker Media.

30. Robinson, Andrew dan Mike Cook. 2014. Raspberry Pi Projects. Chichester: John Wiley \& Sons Ltd.

31. Rohiman, Ao. 2011. Pengertian dan cara kerja router.http://www.catatanteknisi.com/2011/05/pe ngertian-cara-kerja-router.html.

32. Sidik, Betha. 2011. Javascript. Jakarta: Informatika.

33. Wahyu. Pengertian Webcam dan Fungsinya. http://wahyu.blog.fisip.uns.ac.id/2011/12/06/peng ertian-web-cam-dan-fungsinya.

34. Wikipedia. Secure

Digital. https://en.wikipedia.org/wiki/Secure_Digital\#Micr o. 